\title{
Исходный материал для селекции картофеля в Тюменской области
}

\author{
Ю.П. Логинов, К.А. Кендус, А.С. Гайзатулин \\ Государственный аграрный университет Северного Зауралья, Тюмень, Россия \\ *e-mail: kazaknastenka@rambler.ru
}

Успешное решение проблемы импортозамещения в картофелеводстве Тюменской области и Сибири в целом возможно за счет развития селекции этой культуры в местных условиях, а также проведения экологического испытания сортов картофеля отечественной селекции и подбора лучших из них по комплексу хозяйственных признаков для дальнейшего производственного испытания. Успех создания сортов картофеля, адаптированных к условиям Сибири, зависит от наличия и изученности исходного материала. В ГАУ Северного Зауралья на протяжении двух десятилетий изучается коллекция сортов картофеля, собранная из разных селекционных учреждений страны. Она постоянно пополняется новыми генотипами. Проведение полевых и лабораторных оценок позволило создать признаковую коллекцию для дальнейшего использования в селекционных программах. Признаковая коллекция поддерживается в здоровом состоянии за счет репродуцирования ее в условиях Приполярья Тюменской области. При подборе коллекционных сортов особое внимание уделяется генотипам, созданных методом отдаленной гибридизации. Они чаще всего устойчивы ко многим болезням и другим стрессовым факторам. Выделенные источники по хозяйственным признакам могут быть полезными для селекции картофеля на территории Сибири. По урожайности на высоком и среднем фонах питания выделены Снегирь, Чародей, Оредежский, Чароит, Сантэ, Сафо, Башкирский, Спиридон, Романо, Ред Скарлетт, Удача, Жуковский ранний, Сарма, Красное лето, Аладин, Солнечный, Горняк, Ирбитский, Ласунок, Зарево, Северный, Абаканец, Свитанок киевский, Отрада, Луговской, Огонек.

Для селекции на скороспелость выделены источники: Весна, Алена, Адретта, Жуковский ранний, Красноярский ранний, Зов, Колпашевский, Каменский, Укама, Каратоп, Любава, Латона, Метеор, Чароит, Пионер, Полет, Пролисок, Приобский, Розара, Ред Скарлетт, Северный, Якутянка, Алдан, Сарма, Стрелец, Снегирь, Тулунский ранний, Томич, Удача, Уральский ранний, Пушкинец, Бородянский розовый.

Высокую устойчивость к фитофторе (7-9 баллов) имели сорта: Акцент, Архидея, Белорусский-3,Вдохновение, Гусар, Голубизна, Горняк, Загадка Питера, Кузнечанка, Лазарь, Наяда, Нестеровский, Оредежский, Прибрежный, Полонес, Русская красавица, Сарма, Сударыня, Снегирь, Чародей, Хозяюшка.

По крахмалистости (16,3-24,7 \%) выделены источники: Адретта, Алый парус, Бониус, Былина Сибири, Барон, Белоснежка, Верба, Выток, Вдохновение, Зарево, Кибиц, Кузьмич, Ласунок, Лазарь, Лига, Маг, Мавка, Накра, Оригинал, Очарование, Повинь, Сарма, Свитанок киевский, Снегирь, Универсал, Удалец.

Высокие вкусовые качества и нетемнеющую мякоть имели сорта: Чародей, Сказка, Чароит, Адретта, Свитанок киевский, Снегирь, Оредежский, Агрия, Удалец, Карлена, Журавинка, Алый парус, Жемчужина, Очарование, Лига, Голубизна, Ильинский, Сиреневый туман, Даная, Сарма, Зекура, Лина, Люкс, Северный, Амур, Валентина, Тулеевский, Златка, Солнечный. 